\title{
KEPEMIMPINAN VISIONER KIAI \\ DALAM MENGIMPLEMENTASIKAN VISI \\ DI PONDOK PESANTREN
}

\author{
Zuhri \\ IAIN Tulungagung \\ Email: zuhriabdullah@gmail.com
}

\begin{abstract}
Abstrak
Layanan proses pendidikan merupakan integrasi proses dan standar hasil pendidikan. Lembaga pendidikan menerapkan standar layanan dilandasi oleh rancangan masa depan lembaga sebagai organisasi yakni Visi. Lembaga pendidikan mempunyai visi dan tujuan organisasi sebagai pemandu dalam mencapai tujuannya, demikian halnya pondok pesantren. Penelitian ini dilatarbelakangi oleh fenomena yang bertolak belakang terhadap kekuatan visi pondok pesantren dalam menciptakan proses dan layanan pendidikan yang sesuai standar kebutuhan konsumen. Kinerja pimpinan pesantren yakni kiai sangat menentukan visi yang menjadi harakah organisasi pesantren memberikan layanan pendidikan yang prima. Efektifitas organisasi di pondok pesantren sangat bergantung pada kerja kiai sebagai penuntun, motor perubahan lembaga, komunikator, dan pembimbing. Penyajian dalam laporan ini menggunakan formasi Pendahuluan, Metode Penelitian, Pembahasan, dan Penutup.

Kata kunci: Visioner Kiai, Implementasi Visi, Pondok Pesantren.
\end{abstract}

\section{Pendahuluan}

Pesantren merupakan lembaga pendidikan yang berkarakter unik dan berbeda dengan yang lainnya. Secara historis, pendidikan tertua di Indonesia adalah pondok pesantren yang merupakan bentukan pendidikan asli Indonesia. Perkembangan pesantren beriringan dengan masuknya agama Islam di Indonesia dan berkembang menyesuaikan tuntutan pendidikan dan ikut andil dalam mencerdaskan kehidupan bangsa. Secara khusus pesantren bertanggung jawab atas tradisi keagamaan (Islam) dalam arti yang seluas-luasnya.1 Eksistensi pondok pesantren dengan segala aspek kehidupan dan perjuangannya, memiliki

${ }^{1}$ Manfred Opan dan Wrefgang Karcher, Dinamika Pesantren, (Jakarta: P3M, 1987), 89. 
nilai strategis dalam membina insan yang berkualitas baik dimensi iman, ilmu dan amal.

Pesantren yang mempunyai nilai lebih dalam bidang keilmuan dengan transmisi dan internalisasi moral yang menjadikan pesantren sebagai bentuk lembaga pendidikan lokal genius. ${ }^{2}$ Dengan adanya modernisasi yang telah mewarnai setiap aspek kehidupan, pembaharuan yang dilakukan pesantren saangat diperlukan dengan karakteristik tersendiri yakni perubahan mengikuti proses modernisasi yang dinamis tanpa meninggalkan karakter dasar pesantren. Dua hal yang mendasari keunikan pesantren yakni menjawab perubahan sosial di masyarakat dan pemaknaan rahmatal lil alamin keseluruh lapisan bangsa. ${ }^{3}$ Keberadaan pesantren dalam menatap masa depannya telah mengalami kemajuan yang sangat menggembirakan. Hal ini disebabkan adanya komunitas intensif antara para kiai penanggung jawab pesantren dengan para pembaharu Islam. Pondok pesantren yang pada awalnya digunakan tempat mempelajari ilmu agama secara tradisional, kini telah berkembang menjadi sarana pendidikan pada umumnya. ${ }^{4}$

Modernisasi menjadi tantangan tersendiri bagi pesantren yang menuntut bersikap adapatif dan adoptif terhadap sistem baru, serta selalu menyempurnakan kurikulum yang disesuaikan dengan tuntutan zaman. Dalam kehidupan modern ini, kita tidak cukup hanya berbekal moral yang baik, tetapi perlu dilengkapi dengan keahlian (skill) atau keterampilan yang relevan dan sinergis dengan dunia kerja. Untuk menghadapinya, pesantren seyogyanya mempersiapkan sumber daya manusia (SDM) dengan sebaik-baiknya, tidak hanya bertumpu pada kepintaran kognisi yang bersumber pada otak (head) dan kesucian hati

${ }^{2}$ Malik Fajar, Visi Pembaruan Pendidikan Islam (Jakarta: Lembaga Pengembangan Pendidikan dan Penyusunan Naskah Indonesia /LP3NI; 1998), 126.

${ }^{3}$ Said Aqil Siradj (et.al), Pesantren Masa Depan, Wacana Pemberdayaan dan Transformasi Pesantren (Bandung: Pustaka Hidayah, 1999), 202

${ }^{4}$ Ziemik, Manfred, Pesantren dalam Perubahan Sosial, terjemahan Bucthe B. Soedjojo, P3M, Cet.I. (Jakarta: Media Press, 1986), 2 
(heart) semata, tetapi juga harus berorientasi pada keterampilan (hand) sehingga terjalin keselarasan antara ilmu, iman dan amal. Pondok pesantren harus berijtihad untuk mencari format baru untuk kualitas dan mutu pendidikan dan out put bagi santrinya.

Pondok pesantren sebagai salah satu bagian dari lembaga pendidikan tentunya akan mengalami perubahan setiap saat. Perubahan sudah sewajarnya dilakukan oleh pondok pesantren karena perubahan selera masyarakat terhadap pendidikan juga mengalami perubahan. Untuk mewujudkan lembaga pendidikan sesuai kebutuhan konsumen maka sangat dibutuhkan pemimpin yang mempunyai pemikiran inovatif yang diwujudkan dalam pandangan pemimpin yang visioner.

Hal yang mendasar dari pemimpin visioner adalah kemampuannya melihat berbagai kemungkinan yang terdapat dalam sesuatu yang pantas diperjuangan serta mampu menghubungkan kebutuhan dengan kemungkinan yang ada. ${ }^{5}$ Pemimpin visioner di pondok pesantren yang tidak lain adalah seorang kiai sebagai agen utama dalam perubahan lembaga pendidikan yang ada di pesantren. Kehadiran kiai dengan pola kepemimpinan visioner sangat dibutuhkan dalam mewujudkan prubahan pendidikan pesantren yang berkualitas dan terciptanya pelayanan pendidikan yang memenuhi kebutuhan konsumen. Pemimpin memiliki peran peting bagi perubahan lembaga pendidikan karena keberhasilan perubahan lembaga tergantung pada mindset pemimpin serta komitmen menjaga proses perubahan.

Interaksi sosial dan kerjasama dalam suatu organisasi dengan kesatuan visi menjadi kekuatan yang efektif secara individual maupun kelompok. Visi sebagai arah dan pemersatu elemen organisasi akan berfungsi melalui pemimpin yang menyatu secara dhahir dan batin dengan visi organisasi. Visi organisasi sebagai arah dan tujuan organisasi yang menjadi karakter kepemimpinan visioner. Kemampuan pemimpin

${ }^{5}$ Ziemik, Manfred, 48-49. 
menjadi penentu terlaksananya perencanaan aktivitas organisasi yang mencakup pemaparan program, pelaksanaan, evaluasi dan pemecahan masalah sesuai visi organisasi. Pola kepemimpinan ini memberikan dorongan dan kekuatan bagi organisasi dalam berbagai kondisi yang berkembang, sehingga mampu bertahan dengan segala bentuk perubahan yang terjadi. Menurut Arifin, ada enam tanggung jawab pemimpin. Pertama, bertangung jawab atas keselamatan, kesejahteraan, pemotivasian, dan perkembangan anggotanya. Kedua, bertanggung jawab atas keberhasilan dalam pencapaiannya. Ketiga, berkewajiban memberikan komitmen dan layanan spenuhnya bagi para anggota dan masyarakat luas. Keempat, bertanggung jawab mendapatkan bantuan maksimal dari institusi pembantu. Kelima, bertanggung jawab mempromosikan potensi bakat minat bagi anggota memlalui cara yang sehat dan positif. Keenam, bertanggung jawab membangu karakter dan spiritualitas berbasis nilai, ideologi, dan filosofi yang menjadi inspirasi bagi para anggota dan masyarakat luas. ${ }^{6}$

Proses mewujudkan tujuan organisasi dilandasi visi dipengaruhi oleh kemampuan pemimpin secara aktif dan berpartispasi penuh dalam implementasi rencana yang sudah ditetapkan. Posisi pemimpin sebagai patner dalam organisasi memberikan dampak efektifnya komunikasi dan interaksi yang dibangun yang memberikan kemudahan dalam menyelesaikan persoalan-persoalan organisasi. Penyelesaian masalah berdasarkan hasil musyawarah dalam menentukan jalan keluar bersama antara pimpinan dan bawahan. Sumber daya dan fungsi manajemen digerakkan oleh pola kepemimpinan yang mempunyai tanggung jawab tercapainya tujuan organisasi. Indikator kualitas pemimpin dilihat dari kemampuannya memberdayakan seluruh komponen yang ada dalam organisasi terlebih sumber daya personalnya. Peran kepemimpinan dapat

\footnotetext{
${ }^{6}$ Imron Arifin, Kepemimpiann Kepala PAUD dalam mengimplementasikan pembelajaran Sentra studi kasus PAUD/KB Unggulan Nasional Anak Saleh Malang, (Yogyakarta: Aditya Media, 2009), 36.
} 
dilihat dari aspek peran sebagai penentu arah, agen perubahan, juru bicara dan pelatih. Ketiga peran tersebut akan terwujud dengan kemampuan pemimpin mengimplementasikan gaya kepemimpinannya kepada seluruh bawahan agar memamhami tugas dan fungsinya masingmasing. ${ }^{7}$ Peningkatan sumber daya manusia di organisasi merupakan tanggun jawab pemimpin sehingga efektivitas tugas dan perannya sangat ditentukan oleh peranan yang dilaksanakan. Pemahaman karakteristik setiap bawahan yang berbeda menjadi tantangan bagi pemimpin untuk mampu menggerakan dan mengaktifkan kinerja bawahan.

\section{Permasalahan}

Berangkat dari paparan di atas tentang perubahan lembaga pendidikan termasuk di dalamnya Pondok Pesantren yang sangat bergantung pada kepemimpinan visioner Kyai, penulis tertarik mengangkat penelitian tentang kepemimpinan visoner kiai dari Pondok Pesantren Hidayatullah Jombok Pule Trenggalek dalam meningkatkan akses layanan pendidikan pesantren. Pondok Pesantren Hidayatullah mengelola berbagai unit pendidikan baik formal maupun pendidikan non-formal.

Pondok Pesantren Hidayatullah di samping mengelola pendidikan pesantren dan pendidikan formal baik naungan Kementerian Agama maupun Kementerian Pendidikan Nasional juga mengelola berbagai usaha yang berfungsi secara khusus memberikan bekal keterampilan bagi santri dan secara umum memberikan manfaat bagi masyarakat Kecamatan Pule. Kiai sebagai pemegang kekuasaan dan kebijakan tertinggi di pondok pesantren tersebut, berperan dalam melakukan pembaharuan pesantren dengan mengeluarkan berbagai kebijakankebijakan yang bermanfaat bagi kemajuan pesantren. Dalam hal manajemen, sekilas yang peneliti ketahui pondok pesantren Hidayatullah

${ }^{7}$ Werren Bennis \& Burt Nanus, Leaders Strategi untuk Mengemban Tanggung Jawab. (PT. Buana Ilmu Populer Kelompok Gramedia: Jakarta, 2006), 13 
Pule Trenggalek sudah ada penataan manajemen kelembagaan, khususnya pola pembagian kerja yang modern, terstruktur dan terprogram baik, dengan ciri khas berbeda. Sehingga perlu digali mengenai pembagian kerja tersebut sudah berjalan dengan efektif sesuai dengan tugasnya masing-masing atau terjadi adanya tumpang tindih dalam pelaksanaannya.

\section{Pembahasan}

\section{Pondok Pesantren}

\section{ManajemenPondok Pesantren}

Pendidikan pondok pesantren dalam pengertian immaterial cenderung berbentuk suatu upaya perubahan sikap santri, agar santri menjadi seorang pribadi yang tangguh dalam kehidupan sehari-hari. Dalam perkembangannya, misi pendidikan pondok pesantren terus mengalami perubahan sesuai dengan arus kemajuan zaman yang ditandai dengan perkembangan ilmu pengetahuan dan teknologi. Sejalan dengan terjadinya perubahan sistem pendidikannya, fungsi pondok pesantren sebagai lembaga pendidikan mengembangkan sistem pendidikan klasikal disamping bandongan, sorogan, dan wetonan. Juga pendidikan keterampilan kursus-kursus yang semuanya sebagai bekal santri yang bersifat material. ${ }^{8}$

Pola pelaksanaan pendidikan, tidak lagi tergantung pada seorang Kyai yang mempunyai otoritas sebagai figure sacral. Tetapi berfungsi sebagai koordinator. Operasional pendidikan dilaksanakan oleh para guru (ustadz) dengan menggunakan serangkai metode mengajar yang sesuai, sehingga dapat diterima dan dipahami oleh para santri. Hal ini menunjukkan bahwa pesantren telah berkembang dari bentuk salaf ke khalaf atau menunjukkan perubahan dari

8 Bahri Ghazali, Pesantren Berwawasan...2002,37. Lebih lanjut lihat dalam Depag RI, Pola Manajemen Penyelenggaraan Pondok Pesantren, (Jakarta: Dirjen Binbagais, 2001), 33. 
tradisional ke modern. ${ }^{9}$ Secara umum manajemen diartikan sebagai suatu alat yang dapat digunakan oleh para pengambil keputusan atau penganggung jawab lembaga. Beberapa ahli menyatakan manajemen adalah suatu proses, bukan hasil. Dengan demikian alat yang digunakan juga merupakan proses. Ada beberapa unsur yang perlu diperhatikan dalam manajemen, yaitu perencanaan, pengorganisasian, pengarahan, pengkoordinasian dan pengendalian. Dalam sebuah organisasi, keberadaan manajemen merupakan bagian awal yang fundamen dalam pencapaian visi, misi, budaya, struktur, maupun strategi yang akan diterapkan. Hal tersebut seperti ikhtisar gambar berikut:

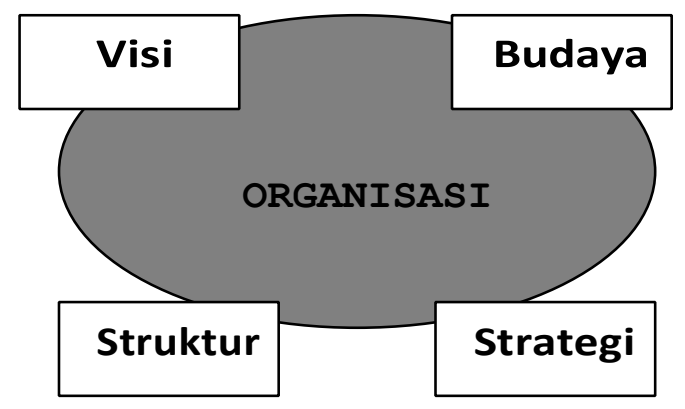

Gambar 2.1 Sub-Sistem Organisasi

Dalam sebuah organisasi secara ideal tersusun dalam sebuah sistem yang meliputi unsur atau sub visi, budaya, struktur dan strategi. Perpaduan ini pada gilirannya akan mementukan pencapaian akhir dari tujuan organisasi, dan secara riil akan mempertegas tahap awal hingga akhir yang meliputi planning dan seterusnya. Koontz menyatakan: "the purpose of every plan and all derrevative plans is to facilitate the accomplishment of enterprise purpose and abjective."10

\footnotetext{
${ }^{9}$ Depag RI. Direktori Pesantren. (Jakarta: Direktorat Pendidikan Keagamaan dan Pondok Pesantren, 2007), 13

10 Harold Koontz, Management; International Student Edition, (Singapore: McGraw-Hill, 1986). 102.
} 
Segala kegiatan dalam suatu organisasi menjadi lebih jelas dengan menggunakan perencanaan, kegiatan-kegiatan yang perlu dilakukan telah disusun secara rapi dan teratur. Dengan manajemen yang baik, maka perjalanan organisasi akan menjadi lebih baik. Tentu saja kalau penerapan menajemen dalam organisasi ini benar-benar dilakukan. Jika penerapannya setengah-setengah, tentunya hasil yang dicapai juga tidak akan memuaskan. Namun perencanaan tersebut tidak pernah digunakan sebagai pedoman di dalam organisasi tersebut. Apalagi fungsi-fungsi yang lain juga diabaikan dengan hanya berbekal perencanaan saja namun tidak ada pengorgansasian, pengarahan, pengkoordinasian, serta pengendalian, tentunya pelaksanaan kegiatan dalam organisasi tersebut tidak akan sebaik yang diharapkan. Secara umum fungsi manajemen digambarkan sebagai berikut:

Tabel 2.1 Fungsi Manajemen

\begin{tabular}{|c|c|c|c|}
\hline $\begin{array}{l}\text { Merencanakan } \\
\text { (Planning) }\end{array}$ & $\begin{array}{c}\text { Mengorganisasikan } \\
\text { (Organizing) }\end{array}$ & $\begin{array}{l}\text { Memimpin } \\
\text { (Leading) }\end{array}$ & $\begin{array}{l}\text { Mengawasi } \\
\text { (Controlling) }\end{array}$ \\
\hline \begin{tabular}{|l|} 
Menetapkan \\
sasaran, \\
merumuskan \\
tujuan, \\
menetapkan \\
strategi, dan \\
membuat strategi, \\
dan \\
mengembangkan \\
sub rencana untuk \\
mengkoordinasikan \\
kegiatan
\end{tabular} & $\begin{array}{l}\text { Menentukan apa } \\
\text { yang perlu } \\
\text { dilaksanakan, cara } \\
\text { pelaksanaannya, } \\
\text { dan siapa yang } \\
\text { melaksanakannya }\end{array}$ & $\begin{array}{l}\text { Mengarahkan dan } \\
\text { memotivasi } \\
\text { semua pihak yang } \\
\text { terlibat dan } \\
\text { memecahkan } \\
\text { pertentangan }\end{array}$ & $\begin{array}{l}\text { Memantau } \\
\text { kegiatan untuk } \\
\text { memastikan } \\
\text { bahwa kegiatan- } \\
\text { kegiatan } \\
\text { diselesaikan } \\
\text { sepeti yang } \\
\text { direncanakan }\end{array}$ \\
\hline
\end{tabular}


Dari konsep tersebut, maka selanjutnya akan memerlukan peran sentral seorang pemimpin (sebut saja manajer, kalau dalam konteks pesantren berarti figur Kyai). Para manajer adalah anggota organisasi yang mengawasi dan mengarahkan pekerjaan anggota yang lain, sehingga manajer adalah seorang anggota organisasi yang memadukan dan mengkoordinasikan pekerjaan orang-orang lain. Mengidentifikasi dengan tepat, siapa manajer dalam organisasi. tidaklah sulit, meskipun harus mengingat bahwa manajer dapat mempunyai berbagai macam nama.

\section{Pondok Pesantren Sebagai Organisasi dan Institusi Pendidikan}

Pondok pesantren merupakan suatu organisasi pendidikan (dalam sistem sosial). Organisasi adalah sistem dari kegiatan manusia yang bekerja sama. Menurut Atchison \& Winston W. Hill, organisasi adalah sistem yang dipolakan orang untuk melaksanakan tujuan atau untuk mencapai sasaran (organization are systems that are designed by people to accomplish some purpose or achieve some goal)" ${ }^{11}$ Definisi tersebut hampir sama maknanya dengan definisi Everett M. Rogerts \& Rekha Agarwala-Rogers bahwa organisasi adalah sistem yang mapan dari orang- orang yang bekerja sama untuk mencapai tujuan bersama melalui suatu jenjang kepangkatan dan pembagian kerja ( $a$ stable sistem of individuals who work together to achieve, through a hi erarchy of ranks and division of labor, common goals). ${ }^{12}$

Mulyono menyatakan bahwa suatu organisasi harus memenuhi beberapa prinsip umum, di antaranya: (1) organisasi harus mempunyai tujuan yang jelas dan kesamaan pandangan seluruh personal yang terlibat di dalamnya; (2) organisasi harus memiliki pimpinan yang mampu mengarahkan para anggotanya dan

\footnotetext{
11 Onong Uchjana Effendy, Human Relation dan Public Relation. (Bandung: Mandar Maju,1993), 2.

12 Ibid, 6
} 
mendelegasikan tugas, wewenang, dan tanggungjawab kepada mereka sesuai dengan bakat, pengetahuan, dan kemampuan mereka; dan (3) organisasi memiliki struktur organisasi yang disusun sesuai dengan kebutuhan sehingga batasan wewenang pekerjaan antarpersonal menjadi jelas. ${ }^{13}$

Berdasarkan beberapa definisi dan prinsip umum organisasi di atas, dapat disimpulkan bahwa organisasi adalah kumpulan dua orang atau lebih yang membentuk kerja sama dalam satu wadah untuk mencapai visi, misi, dan tujuan bersama secara efektif dan efisien. Terdapat tiga hal penting yangharus dimiliki organisasi. Pertama, adanya visi, misi dan tujuan. Sebab tanpa visi, misi dan tujuan tidak ada alasan organisasi tersebut dibentuk. Kedua, untuk mencapai tujuan, maka setiap organisasi perlu menyusun dan memiliki program, dan menentukan metode bagaimana program itu dapat dilaksanakan. Ketiga, setiap organisasi akan memiliki pimpinan atau manajer yang bertanggungjawab terhadap organisasi dalam mencapai tujuan. Halhal tersebut menunjukkan betapa pentingnya peranan manajemen dalam eksistensi suatu organisasi. Oleh sebab itu, kegiatan administrasi, manajemen, dan kepemimpinan merupakanrangkaian kegiatan yang perlu dilaksanakan di setiap organisasi, termasuk di lembaga pendidikan pondok pesantren.

Umat Islam memang dituntut untuk meningkatkan pengetahuan yang cukup untuk berubah dan membina kehidupannya sehingga mereka dapat mencapai masa depannya yang lebih gemilang. Perkembangan dewasa ini menuntut adanya pembinaan terhadap nilai dan sikap yang dilaksanakan secara seimbang antara pendidikan cognitive (pengetahuan dan kecerdasan), psychomotor (ketrampilan dan kekaryaan), dan affective (mental, emosi, perasaan)

13 Mulyono. Manajemen Administrasi dan Organisasi Pendidikan. (Yogyakarta: Ar Ruzz Media Groups,2009), 72 
yang dilandasi dengan keimanan dan ketakwaan kepada Allah SWT serta kepedulian terhadap lingkungan dan masyarakat sekitar. ${ }^{14}$

Organisasi dapat dilihat dari dua aspek. Pertama, aspek struktur organisasi. Aspek ini meliputi pengelompokan orang secara formal dan bagan organisasi. Kedua, aspek proses perilaku. Setelah struktur organisasi dengan manusia/orang, maka terjadi proses perilaku. Proses perilaku adalah aktivitas kehidupan dalam struktur organisasi, antara lain: (1) komunikasi; (2) pembuatan keputusan; (3) motivasi; dan (4) kepemimpinan. ${ }^{15}$

Asas pendidikan yang integral dan komprehensif seperti inilah yang diupayakan pengejawantahannya melalui sistem pendidikan nasional dan peranan pondok pesantren di dalamnya tentu akan lebih signifikan.

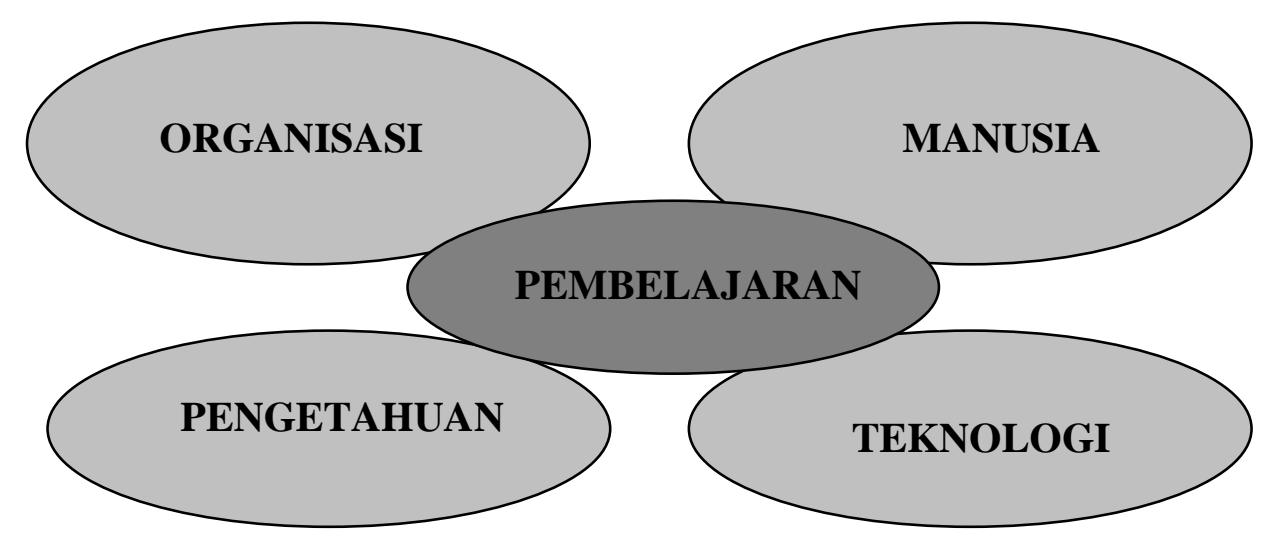

Gambar 2.2 Model Sistem Organisasi Pembelajaran

Dalam rangka mencapai keberhasilan dari tujuan pendidikan pesantren diperlukan adanya unsur-unsur yang dikelompokkan sebagai berikut:

Aktor atau pelaku yaitu Kyai, ustadz, santri dan pengurus pesantren. Sarana perangkat keras misalnya: masjid, rumah Kyai dan

\footnotetext{
14 Mahmud Yunus, Sejarah Pendidikan Islam di Indonesia, (Jakarta: Hidakarya Agung, 1985), 12.

${ }^{15}$ Mulyono. Manajemen Administrasi 2009,73
} 
perumahan. Ustadz, asrama santri (gotha'an: Jawa), gedung madrasah, lapangan olahraga, lahan peternakan, kantin, koperasi dan sebagainya. Sarana perangkat lunak seperti tujuan perpustakaan, pusat dokumentasi pusat informasi, metode pengajaran, laboratorium, pusat pelayanan masyarakat dan alat-alat pendidikan lainnya. ${ }^{16}$

Pendidikan sebagai salah satu sistem meliputi berbagai komponen yang akan membentuk keutuhan esensi. Perubahan kebijaksanaan pendidikan termasuk pendidikan di pesantren. Hal ini akan melibatkan banyak fihak yang terkait, sehingga terjadinya pendidikan tersebut tidak akan secara kebetulan, melainkan dipengaruhi oleh beberapa faktor, antara lain: Pola kepemimpinan di dalam pesantren. Keterkaitannya dengan berbagai sistem yang terjadi di masyarakat. Arus budaya yang tersebar di berbagai sektor kehidupan masyarakat. Tuntutan masyarakat yang semakin komplek. Perkembangan ilmu pengetahuan dan teknologi. ${ }^{17}$

Menurut Hadari Nawawi, asas-asas dalam organisasi Pendidikan adalah: (1) organisasi harus professional; pengelompokan satuan kerja harus menggambarkan pembagian kerja; (3) organisasi harus mengatur pelimpahan wewenang dan tanggung jawab; (4) organisasi harus mencerminkan rentangan control; organisasi harus mengandung kesatuan perintah; (6) organisasi harus fleksibel dan seimbang. ${ }^{18}$

Dari beberapa pendapat di atas maka dapat diambil kesimpulan bahwasanya dalam organisasi pendidikan terdapat azas-azas penting yaitu pertama, organisasi harus profesional, yaitu dengan pembagian satuan kerja yang sesuai dengan kebutuhan. Kedua, pengelompokan satuan kerja harus menggambarkan pembagian kerja, artinya beban

16 Soedjojo Prasodjo dkk, Beberapa Unsur Keberhasilan Tujuan Pendidikan Pondok Pesantren Profil Pesantren, (Jakarta: LP3ES, 1973), 23.

17 Mujammil, Melacak Transformasi Institusi; Kurikulum dan Metode Pendidikan Pesantren, Cet.I. (Jakarta: Al-Ikhlas, 1993), 101.

18 Mulyono. Manajemen Administrasi ...2009, 77. 
kerja setiap satuan kerja harus memiliki batas-batas yang jelas dan sebanding pada tiap-tiap tingkatnya. Ketiga, organisasi harus mengatur pelimpahan wewenang dan tanggung jawab, dengan demikian setiap anggota melaksanakan pekerjaannya sesuai dengan beban tugas masing-masing. Keempat, organisasi harus mencerminkan rentangan kontrol. Kelima, organisasi harus mengandung kesatuan perintah yang jelas antara pimpinan dengan anggota organisasi sehingga tidak terjadi tumpang tindih dalam pelaksanaan kerja. Keenam, organisasi harus fleksibel dan seimbang, sehingga bila terjadi perubahan atau penambahan volume kerja maka struktur organisasi harus disesuaikan dengan kebutuhan tersebut. Azasazas penyusunan kelembagaan inilah yang hendaknya ada di tiap organisasi pendidikan termasuk lembaga pendidikan pondok pesantren.

\section{Visionary Leadership Kyai}

Kepemimpinan, didefinisikan oleh Robin bahwa kepemimpinan adalah kemampuan untuk mempengaruhi suatu kelompok kearah pencapaian tujuan. ${ }^{19}$ Menurut Terry seperti dikutip Ahmad Fauzi, Pemimpin menunjukan posisi, sedangkan kepemimpinan menunjukkan kepada proses atau aktifitas mempengaruhi. ${ }^{20}$ Kepemimpinan merupakan prilaku untuk mempengaruhi individu atau kelompok untuk melakukan sesuatu dalam rangka tercapainya tujuan organisasi. Secara lebih sederhana di bedakan antara kepemimpinan dan menejemen, yaitu pemimpin mengerjakan sesuatu yang benar (People who do think right), sedangkan menejer (People do right think). ${ }^{21}$ Landasan inilah yang menjadi acuan mendasar untuk melihat peran pemimpin dalam suatu organisasi. Perbedaan ini memberikan gambaran bahwa pemimpin biasanya terkait

\footnotetext{
19 Wahyosumidjo, Kepemimpinan Kepala Sekolah, Tinjauan Teoretik dan Permasalahanya (Jakarta: Rajawali Pres, 2010), 104.

20 Ahmad Fauzi, "Pengaruh Prilaku Pemimpin dan Penggunaan Kekuasaan Terhadap Efektivitas Kepemimpinan Kepalah Sekolah Dasar Negeri Se Kota Pasuruhan" (Tesis-Universitas Widiya Gama Malang, Malang, 2006), 4.

${ }^{21}$ Butr Namus, Kepimpinan Visione (Jakarta: Prenhallindo, 2001) 19.
} 
dengan tingkat pucak atau pengambil keputusan puncak yang bersifat menyeluruh dalam organisasi, sedangkan menejerial merupakan pengambilan keputusan tingkat menengah. ${ }^{22}$

Kepemimpinan didefinisikan sebagai kekuatan untuk menggerakkan dan mepengaruhi orang. Kepemimpinan sebagai sebuah alat, sarana atau proses untuk membujuk orang agar bersedia melakukan sesuatu secara sukarela atau sukacita. Ada beberapa faktor yang dapat menggerakan orang yaitu: karena ancaman, penghargaan, otoritas, dan bujukan. Aktivitas kepemimpinan memang sangat penting dalam suatu organisasi, di mana pentingnya pemimpin dan kepemimpinan yang baik adalah:23 Sebagai pengatur, pengarah aktivitas organisasi untuk mencapai tujuan. Penanggung jawab dan pembuat kebijakan-kebijakan organisasi. Pemersatu dan memotivasi para bawahannya dalam melaksanakan aktivitas organisasi. Pelopor dalam menjalankan aktivitas manajemen, yaitu perencanaan, pengorganisasian, pengarahan, dan pengawasan serta pengelolaan sumber daya yang ada. Sebagai pelopor dalam memajukan organisasi dan lain-lain.

Menurut Tanthowi, kriteria kemampuan yang harus ada pada seorang pimpinan adalah sebagai berikut: Melihat organisasi secara keseluruhan. Mengambil keputusan. Melaksanakan pendelegasian. Memimpin sekaligus mengabdi. ${ }^{24}$

Pemimpin merupakan pribadi yang memiliki ketrampilan teknis, khususnya dalam suatu bidang, sehingga mampu mempengaruhi orang lain untuk bersama-sama melakukan aktivitas, demi pencapaian tujuan organisasi. Seorang pemimpin yang memiliki born leader dianggap mempunyai sifat unggul yang dibawa sejak lahir, sifatnya khas dan unik, tidak dimiliki atau tidak dapat ditiru oleh orang lain. Namun pada masa

22 Rasmianto "Kepemimpina Kepala Sekolah berwawasan Visioner-Transformatif, 15-16.

${ }^{23}$ Ach Mohyi, Teori \& Prilaku Organisasi Trioningsih-Ratih Juliati (ed) UMM: (Malang, 1999), 176

24 Tanthowi Jawahir, Unsur-unsur Manajemen Menurut Ajaran Alquran (Jakarta: Pustaka AlHusna, 1983), 37. 25 
sekarang dengan berbagai kegiatan-kegiatan yang serba modern dan kompleks, di mana-mana selalu dibutuhkan pemimpin.

Kepemimpinan merupakan faktor yang sangat dominan dalam menentukan berhasil tidaknya suatu organisasi. Memimpin adalah sebuah aktivitas yang menyangkut pihak yang memimpin dan pihak yang dipimpin. Tanpa kerjasama antara kedua belah pihak yang berkepentingan maka sulit dapat diharapkan akan tercapainya sasaransasaran. Memimpin manusia merupakan salah satu bagian penting dari pada usaha-usaha (actuating). Kepemimpinan sebagai salah satu fungsi manajemen merupakan hal yang sangat penting untuk mencapai tujuan organisasi. Seolah-olah kepemimpinan dipaksa menghadapi berbagai macam faktor seperti: struktur atau tatanan, koalisi, kekuasaan dan kondisi lingkungan organisasi. Sebaliknya kepemimpinan rasanya dapat dengan mudah menjadi satu alat penyelesaian yang luar biasa terhadap persoalan yang menimpa organisasi. ${ }^{25}$

Siagian mengartikan kepemimpinan adalah kemampuan untuk mempengaruhi dan mengerahkan orang agar rela, mampu dan dapat mengikuti keinginan manajemen demi tercapainya tujuan yang telah ditentukan sebelumnya dengan efisien, efektif dan ekonomis.26 Sedangkan Hersey dan Blancard, mendefinisikan kepemimpinan adalah leadership is the process of influencing the activities of an individual or a group in efforts toward goal achievement in a given situation. Kepemimpinan merupakan proses mempengaruhi aktivitas seseorang ataupun kelompok untuk mencapai tujuan dalam situasi tertentu.27 Terry mendefinisikan kepemimpinan yaitu: leadership is the relationship in which one person, the leader influences others to work together willingly on related task

\footnotetext{
${ }^{25}$ Ibid. 15

${ }^{26}$ Siagian S., Fungsi-fungsi Manajerial, (Jakarta: Bumi Aksara, 2002), 97.

${ }^{27}$ Hersey P. \& Blanchard K., Management of Organization Behavior, (New Jersey Englewood Cliffs, 1993), 83.
} 
to attain that hick the leader desires. ${ }^{28}$ Sedangkan menurut Anderson sebagaimana dikutip Arief Daryanto dan Heny KS. Drayanto mendefinisikan "leadership means using power to influence the thought and actions of others in such a way that achieve high performance. ${ }^{29}$

Berdasarkan definisi-definisi di atas kepemimpinan memiliki beberapa implikasi. Pertama, kepemimpinan berarti melibatkan orang atau pihak lain, yaitu para anggota, karyawan, bawahan, dan staf. Para anggota atau bawahan harus memiliki kemauan untuk menerima arahan dari pemimpin. Walaupun demikian, tanpa adanya anggota atau karyawan, pemimpin tidak akan ada gunanya sama sekali. Kedua, merupakan seorang pemimpin yang efektif adalah seseorang yang dengan kekuasaan dan tanggungjawabnya ia mampu memotivasi para anggota atau karyawannya untuk mencapai kinerja yang memuaskan, sesuai dengan visi, misi dan tujuan organisasi yang telah ditetapkan bersama, serta responsif terhadap perubahan- perubahan dan perkembangan yang terjadi. Sehingga dengan demikian kepemimpinan diarahkan untuk dapat mencapai sebuah perubahan yang tetap berpijak pada visi, misi dan tujuan organisasi.

Kyai merupakan Central Figure setiap Pondok Pesantren. Central Figure Kyai bukan saja karena keilmuannya, melainkan juga karena Kyai lah yang menjadi pendiri, pemilik, dan pewakaf pesantren itu sendiri, perjuangan nya tak terbatas pada ilmu, tenaga, waktu, tetapi juga tanah dan materi lainnya diberikan demi kemajuan syiar Islam.30 Sedangkan muthohar menyatakan baha Kyai adalah tokoh Kharismatik yang diyakini

\footnotetext{
28 Terry G., Principles of Management, (Amerika: Richard D. Irwin Inc, 1997), 410.

29 Arief Daryanto dan Heny KS. Daryanto, Model Kepemimpinan dan Pemimpin Agrobisnis di Masa Depan, (Bogor: Jurnal Magister Manajemen Agrobisnis IPB, 1999), 3.

30 Babun Suharto, Dari Pesantren Untuk Umat. (Surabaya: Imtiyaz,2011), 84
} 
memiliki pengetahuan agama yang luas sebagai pemimpin sekaligus pemilik. ${ }^{31}$

Kyai pesantren dipandang kharismatik oleh masyarakat dan tidak boleh digugat juga menjadi variable penentu ketahanan pesantren, dalam kedudukan seperti itu Kyai dapat juga disebut agent of change dalam masyarakat yang berperan penting dalam suatu proses perubahan sosial. Berangkat dari teori tersebut dapat disimpulkan bahwa Kyai berperan terhadap ketahanan pesantren selain dari pada akomodasi pesantren terhadap perubahan, keterkaitan pesantren dengan komunitas lingkungannya dan posisi kharismatik Kyai sebagai pimpinan pesantren. ${ }^{32}$

Kyai adalah orang yang memiliki ilmu agama (Islam) plus amal dan akhlak yang sesuai dengan ilmunya. Menurut Saiful Akhyar Lubis, menyatakan bahwa "Kyai adalah tokoh sentral dalam suatu pondok pesantren, maju mundurnya pondok pesantren ditentukan oleh wibawa dan kharisma sang Kyai. Karena itu, tidak jarang terjadi, apabila sang Kyai di salah satu pondok pesantren wafat, maka pamor pondok pesantren tersebut merosot karena Kyai yang menggantikannya tidak sepopuler Kyai yang telah wafat itu". ${ }^{33}$

Menurut Nurhayati Djamas mengatakan bahwa "Kyai adalah sebutan untuk tokoh ulama atau tokoh yang memimpin pondok pesantren".34 Sebutan Kyai sangat populer digunakan di kalangan komunitas santri. Kyai merupakan elemen sentral dalam kehidupan pesantren, tidak saja karena Kyai yang menjadi penyangga utama kelangsungan sistem pendidikan dipesantren, tetapi juga karena sosok Kyai merupakan cerminan dari nilai yang hidup di lingkungan komunitas santri. Kedudukan dan pengaruh Kyai terletak pada keutamaan yang

\footnotetext{
${ }^{31}$ Ahmad Muthohar, Ideologi Pendidikan Pesantre, (Semarang: Pustaka Rizki Putra,2007), 103.

32 Ali Anwar, Pembaharuan Pendidikan di Pesantren Lirboyo Kediri. (Yogyakarta: Pustaka Pelajar,2011), 32

33 Zamakhsyari Dhofier, Tradisi Pesantren; Studi.... 1982, 55.

${ }^{34}$ Ibid. 56.
} 
dimiliki pribadi Kyai, yaitu penguasaan dan kedalaman ilmu agama, kesalehan yang tercermin dalam sikap dan perilakunya seharihari yang sekaligus mencerminkan nilai-nilai yang hidup dan menjadi ciri dari pesantren seperti ikhlas, tawadhu', dan orientasi kepada kehidupan ukhrowi untuk mencapai riyadhah.

Menurut Munawar Fuad Noeh menyebutkan ciri-ciri Kyai diantaranya yaitu:

Tekun beribadah, yang wajib dan yang sunnah. Zuhud, melepaskan diri dari ukuran dan kepentingan materi duniawi Memiliki ilmu akhirat, ilmu agama dalam kadar yang cukup. Mengerti kemaslahatan masyarakat, peka terhadap kepentingan umum. Dan mengabdikan seluruh ilmunya untuk Allah SWT, niat yang benar dalam berilmu dan beramal. ${ }^{35}$

Kedudukan Kyai salah satu unsur terpenting dalam pondok pesantren, ia merupakan sosok paling berperan. Dalam diri Kyai terdapat beberapa kemampuan, diantaranya yaitu: ia sebagai perancang (arsitektur), pendiri dan pengembang (developer), dan sekaligus sebagai seorang pemimpin dan pengelola (leader and manager) pesantren. Kepemiminan merupakan salah satu topik yang selalu menarik untuk dikaji dan diteliti, karena paling banyak diamati dan sekaligus fenomena yang paling sedikit dipahami. Karakteristik kepemimpinan Kyai yang efektif menurut Dubin, yaitu mampu memenuhi tiga hal, ialah (a) cerate an atmosphere conducive for student learning (menciptakan iklim yang kondusif bagi murid untuk belajar); (b) teacher involvement and growt (para guru terlibat dan bertumbuh); (c) community support and high expectations (seluruh masyarakat memberikan dukungan dan menaruh harapan yang tinggi. 36

${ }^{35}$ Zamakhsyari Dhofier, Tradisi Pesantren ....1985, 22.

${ }^{36}$ Dubin, The Principal as Chief Executive Officer, (London: The Falmer Press, 1991), hlm. 49 
Menurut Hamdan Rasyid bahwa Kyai mempunyai tugas di antaranya Pertama, Melaksanakan tablikh dan dakwah untuk membimbing umat. Kyai mempunyai kewajiban mengajar, mendidik dan membimbing umat manusia agar menjadi orang-orang yang beriman dan melaksanakan ajaran Islam. Kedua, Melaksanakan amar ma`ruf nahi munkar. Seorang Kyai harus melaksanakan amar ma`ruf dan nahi munkar, baik kepada rakyat kebanyakan (umat) maupun kepada para pejabat dan penguasa Negara (umara), terutama kepada para pemimpin, karena sikap dan perilaku mereka banyak berpengaruh terhadap masyarakat. Ketiga, Memberikan contoh dan teladan yang baik kepada masyarakat. Para Kyai harus konsekwen dalam melaksanakan ajaran Islam untuk diri mereka sendiri maupun keluarga, saudara-saudara, dan sanak familinya. Salah satu penyebab keberhasilan dakwah Rasulullah SAW, adalah karena beliau dapat dijadikan teladan bagi umatnya. Keempat, Memberikan penjelasan kepada masyarakat terhadap berbagai macam ajaran Islam yang bersumber dari al-Qur'an dan al- Sunnah. Para Kyai harus menjelaskan hal-hal tersebut agar dapat dijadikan pedoman dan rujukan dalam menjalani kehidupan. Kelima, Memberikan Solusi bagi persoalan-persoalan umat. Kyai harus bisa memberi keputusan terhadap berbagai permasalahan yang dihadapi masyarakat secara adil berdasarkan al-Qur`an dan al-Sunnah. Keenam, Membentuk orientasi kehidupan masyarakat yang bermoral dan berbudi luhur. Dengan demikian, nilainilai agama Islam dapat terinternalisasi kedalam jiwa mereka, yang pada akhirnya mereka memiliki watak mandiri, karakter yang kuat dan terpuji, ketaatan dalam beragama, kedisiplinan dalam beribadah, serta menghormati sesama manusia. Jika masyarakat telah memiliki orientasi kehidupan yang bermoral, maka mereka akan mampu memfilter infiltrasi budaya asing dengan mengambil sisi positif dan membuang sisi negatif. Ketujuh, Menjadi rahmat bagi seluruh alam terutama pada masa-masa kritis seperti ketika terjadi ketidak adilan, pelanggaran terhadap Hak-hak 
asasi manusia (HAM), bencana yang melanda manusia, perampokan, pencurian yang terjadi dimana-mana, pembunuhan, sehingga umatpun merasa diayomi, tenang, tenteram, bahagia, dan sejahtera di bawah bimbingannya.37 Kepemimpinan sebenarnya bukanlah sesuatu yang menyenangkan, tetapi merupakan tanggung jawab sekaligus amanah yang amat berat dan harus diemban sebaik-baiknya. Hal tersebut dijelaskan dalam Alquran Surat Al- Mu'minun ayat 8-11:

"dan orang-orang yang memelihara amanat-amanat (yang dipikulnya) dan janjinya (8), dan orang-orang yang memelihara sembahyangnya (9), mereka Itulah orang-oran yang akan mewarisi, (10), (yakni) yang akan mewarisi syurga Firdaus mereka kekal di dalamnya.(11)."38

Dari penjelasan Alquran surat al-Mukminun8-11 di atas dapat diambil suatu benang merah bahwa dalam ajaran Islam seorang pemimpin harus mempunyai sifat amanah, karena seorang pemimpin akan diserahi tanggung jawab, jika pemimpin tidak memiliki sifat amanah, tentu yang terjadi adalah penyalahgunaan jabatan dan wewenang untuk hal-hal yang tidak baik. Oleh karena itu, kepemimpinan sebaiknya tidak dilihat sebagai fasilitas untuk menguasai, tetapi justru dimaknai sebuah pengorbanan dan amanah yang harus diemban sebaikbaiknya. Selai bersifat amanah seorang pemimpin harus mempunyai sifat yang adil. Hal tersebut ditegaskan oleh Allah dalam firmannya Surat AnNisa' ayat 58:

"Sesungguhnya Allah menyuruh kamu menyampaikan amanat kepada yang berhak menerimanya, dan (menyuruh kamu) apabila menetapkan hukum di antara manusia supaya kamu menetapkan dengan adil. Sesungguhnya Allah memberi pengajaran yang sebaik-baiknya

\footnotetext{
${ }^{37}$ Wahjosumidjo, Kepemimpinan Kepala Sekolah: Tinjauan Teoritis dan Permasalahannya, Cet. III., (Jakarta: PT. RajaGrafmdo Persada, 2002), 15.

38 Departeman Agama RI, Al Qur'an dan ......2005, $273^{40} \mathrm{Ibid}, 69$
} 
kepadamu. Sesungguhnya Allah adalah Maha mendengar lagi Maha melihat." 39

Dari paparan di atas dapat diambil suatu maksud bahwa kepemimpinan Kyai adalah sebuah amanah yang harus diemban dengan sebaik-baiknya, dengan penuh tanggung jawab, profesional dan keikhlasan. Sebagai konsekuensinya pemimpin harus mempunyai sifat amanah, profesional dan juga memiliki sifat tanggung jawab. Kepemimpinan bukan kesewenang-wenangan untuk bertindak, tetapi kewenangan melayani untuk mengayomi dan berbuat seadil-adilnya. Kepemimpinan adalah keteladanan dan kepeloporan dalam bertindak yang seadil- adilnya. Kepemimpinan semacam ini hanya akan muncul jika dilandasi dengan semangat amanah, keikhlasan dan nilai-nilai keadilan

\section{Implementasi Visi}

Implementasi visi oleh Kyai pada situs Pondok Pesantren Hidayatullah dalam layanan informasi bahwa memodifikasi layanan menjadi dua bagian; informasi internal yang hak aksesnya pada pengelola pendidikan dan informasi eksternal yang hak aksesnya bebas untuk semua pengguna jasa pendidikan Pondok Pesantreen Hidayatullah. Langkah yang ditempuh meningkatkan layanan informasi eksternal melalui jaringan website pondok hidayatullah, jaringan medsos santri dan alumni yang terstruktur, media cetak, program book of years yang memuat progress pondok setiap tahunnya, dan memanfaatkan jaringan youtuber dengan indikasi semakin banyak follower semakin membuka peluang informmasi tersebar, dan media radio Haya milik pondok pesantren.

Sedangkan layanan informasi internal melalui "Integrated System Information Haya" (Isy-Haya) dengan data base yang dikelola oleh admin pusat pondok pesantren dengan sistem link conection antar lembaga

${ }^{39}$ Kartono Kartini, Pemimpin dan Kepemimpinan. Apakah Kepemimpinan Abnormal itu..? (Jakarta. Raja Grafindo Persada, 2001), 56. 
naungannya sehingga proses informasi internal dapat cepat, tepat dam efektif. Yang ditemukan disitus penelitian ini, sistem pendaftaran santri baru sudah menggunakan sistem online yang support dengan media seperti android. Seluruh data santri baru yang masuk ke pondok pesantren merupakan hak akses admin sentral baik entry dan pengolahan data, lembaga pendidikan tinggal menunggu hasilnya dengan sistem download base PSB di Isy-Haya. Sistem ini diterapkan akan mempermudah seluruh akses informasi antar lembaga pendidikan, antar bidang usaha, dan pondok pesantren.

Implementasi Kyai dalam layanan administrasi dipondok Pesantren Hidayatullah menggunakan sistem "Adisy-Haya" (Admin Intergated System of Hidayatullah). "Adisy-Haya" adalah sistem adminitrasi terpusat pondok pesantren Hidayatullah khusus bidang non edukatif seperti bidang keuangan, sarana, logistik santri, dan asrama. Sistem ini menggunakan data base induk yang terhubung keseluruh bagian administrasi lembaga pendidikan, lembaga keuangan pondok, lembaga usaha pondok, dan pondok pesantren itu sendiri. Data base sudah mencakup seluruh kebutuhan admistrasi di setiap lembaga naungan pondok pesantren hidayatullah sebagai bentuk pelayanan administasi yang mudah dan efesien.

Adapun implementasi visi oleh Kyai dalam layanan sarana prasarana pendidikan pada situs pondok pesantren hidayatullah menggunakan asas santri tidak terbebani kurangnya saran pendidikan dan pendukungya sehingga proses pendidikan terganggu. Sarana pilihan lembaga pendidikan tempat tersedia mula jenjang TK sampai SLTA, sarana pendidikan setiap lembaga dipenuhi sesuai kebutuhan dan menyesuaikan standar pelayanan sarana pendidikan dari pemerintah, santri diberikan layanan fasilitas kreatifitas berkarya baik itu bidang seni, ketrampilan, sains, dan kebahasaan. Pondok pesantren juga memberikan fasilitas transportasi bagi santri yang tidak mukim, fasilitas kesehatan 
rutin cek setiap akhir pekan di Pos Kesehatan Pesantren (Poskestren) ditangani 1 orang dokter dan 2 orang tenaga medis, kebutuhan logistik harian santri disediakan dengan layanan catering dan laundry, dan untuk memenuhi kebutuhannya pondok menyediakan mini market dan Haya mart. Seluruh kebutuhan santri intergrated pembiayaan dalam satu paket biaya pendidikan pondok pesantren dan adanya sistem bantuan biaya pendidikan bagi santri yang tidak mampu.

Dalam layanan bimbingan dan pengembangan bakat minat santri, implementasi visi yang dilakukan Kyai pada situs Pondok Pesantren Hidayatullah dengan sistem "Home Base Edacation System Haya" yakni program pendidikan pondok salafi, program pendidikan berbasi pesantren, program pendidikan terpadu, dan di perkuat dengan pilar Akhlak, Agama, Bahasa, dan Wirausaha yang diterapkan di lembaga pendidikan SD, SMP, SMK, MTS, dan MA dengan rutinitas harian pembimbingan mulai pukul 03.00 sampai pukul 22.00 WIB. Langkah mendongkrak peningkatan Besy-haya pondok pesantren bidang Tahfidzil Qur'an dan program 100 hari menciptakan metode Al Qur'an mandiri yakni Metode Al Qu'r'an Haya. Langkah pengembangan bakat dan minat santri pondok pesantren menfasilitasi berbagai bidang ketrampilan usaha, dan mengawal siswa yag melanjutkan ke perguruan dengan sistem penjaminan di terima di perguruan tinggi yang di pilih.

Implementasi visi oleh Kyai dalam layanan kesejahteraan pada sistus pondok pesantren hidayatul yakni memberikan jaminan kesejahteraan bagi para pendidik, pengelola pendidikan dan karyawan yang bekerja keras mewujudkan pendidikan berdaya saing dan bermutu. Layanan kesejahteraan dalam bentuk reward tugas waji, tugas tambahan, penghargaan masa pengabdian, tunjangan keluarga, tunjangan kesehatan, dan tunjangan hari raya. Setiap tenaga pengelola pendidikan di pondok pesantren hidayatullah tingkat kesejahteraannya diatas UMR kabupaten Trenggalek atau minimal setara dengan pegawai negeri sipil golongan $3 \mathrm{~A}$. 
Orientasi kesejahteraan yang diberikan dapat memberikan rasa nyaman, tenang, dan giat bagi pengelola pendidikan melaksanakan tugasnya.

Berdasarkan hasil penelitian diatas tentang implementasi visi dalam layanan informasi, layanan administrasi, layanan sarana prasarana, layanan bimbingan, bakat, dan minat, dan layanan kesejahteraan menggambarkan Kyai Visioner dalam mengimplementasikan visi bekerja dengan menerapkan peranya sebagai penentu arah, agen perubahan, komunikator, dan pembimbing.

1. Kyai sebagai Penentu Arah

Para pemimpin dalam melaksanakan kepemimpinan pada sebuah organisasi dituntut melaksanakan peran kepemimpinan untuk meningkatkan kemampuan sumber daya manusia agar dapat lebih efektif dalam melaksanakan tugas dan tanggung jawabnya sebagai pelaksana administrasi dalam sebuah organisasi. Untuk mempengaruhi sumberdaya pegawai kearah pencapaian tujuan, tidak semudah apa yang dibayangkan, karena sumber daya pegawai memiliki karakteristik yang berbeda-beda, sehingga membutuhkan gaya kepemimpinan seorang pemimpin untuk menggerakkannya. Gaya kepemimpinan merupakan norma perilaku yang digunakan oleh seseorang pada saat orang tersebut mencoba mempengaruhi perilaku orang lain. ${ }^{40}$

Kepemimpinan visioner Kyai ma'shum sebagai penentu arah dilakukan dengan mengkomunikasikan visi kepada seluruh komponen pondok pesantren Hidayatullah baik dari secara horizontal maupu vertikal. Komunikasi dilakukan dengan lisan, tulisan, dan aksi program yang dapat dibuktikan langsung oleh wali santri. Secara lisan visi pondok pesantren disampaikan melalui pertemuan dengan seluruh komponen pesantren dalam bentuk rapat dan pertemuan yang tidak formal. Setiap waktu pertemuan dengan pihak internal dan

40 Thoha, Kepemimpinan dalam Manajemen. (Jakarata: Raja Grafindo Persada, 2004), 51 
ekternla beliau selalu mengungkap visi pondok pesantren hidayatullah dalam memberikan layanan prima yang prima. Komunikasi visi melalui tulisan disampaikan dengan pajangan visi digerbang masuk pesantren, pencantuman visi pesantren pada setiap hasil produksi pondok pesantren dalam bidang usaha pesantren seperti tertera pada label barang produksi, visi disyiarkan melalui media internet, brosur, baliho diluar area pondok pesantren Hidayatullah.

Diantara visi yang dikomunikasikan oleh Kyai Ma'shum adalah nilainilai akhlak dan pembinaan yang duterapkan melalui program Agama Akhlak Bahasa (AAB) dan Agama Akhlak Wirausaha (AAW). Kedua program tersebut menjadi pilar pondok pesantren Hidayatullah dalam memberikan layanan prima pesantren dengan optimal dan prima. Beliau menanamkan keyakinan kepada santri dan pengelola pendidikan bahwa sebaik-baiknya manusia adalah manusia yang bermanfaat bagi sesama. Istilah ini oleh Kyai Ma'shum dalam visinya di isyaratkan dengan "membumi" yang mengandung arti dapat bertempat dimana saja, bermanfaat bagi siapa saja dan tidak merepotkan dimananpun berada. Kepemimpinan sebagai penentu arah, pemimpin mengarahkan pengikutnya ke arah pencapaian tujuan organisasi. Jika pemimpin tidak memahami kondisi pengikut, pemimpin di dalam bertindak sebagai penentu arah, bagaikan alat (kompas) penentu arah yang digunakan oleh seorang nahkoda di tengah laut kemana tujuan dan sasaran yang dituju, dan juga berupaya mengembangkan moral bawahan agar bekerja sepenuh hati. ${ }^{41}$

Dalam Al Qur'an tertera menyiratkan kepemimpinan visioner berorienttasi mempunyai kemampuan yang baik untuk menjadi pemberi petunjuk dan penentu arah bagi organisasi yang dipimpinnya. Firman Allah dalam surat Al Anbiya ayat 21:

${ }^{41}$ Winardi, kepemimpinan dalam manajemen, (Jakarta; Rineka Cipta, 2000), 165 
"Kami telah menjadikan mereka itu sebagai pemimpinpemimpin yang memberi petunjuk dengan perintah Kami dan telah Kami wahyukan kepada, mereka mengerjakan kebajikan, mendirikan sembahyang, menunaikan zakat, dan hanya kepada kamilah mereka selalu menyembah" 42

Ayat tersebut menegaskan bahwa seorang pemimpin tidak hanya mampu menjelaskan arah tetapi juga mampu mmangantar pengikutnya menuju jalan yang benar dan baik.

2. Kyai sebagai Agen Perubahan

Kyai Ma'shum adalah agen perubahan yang bertanggung jawab menggugah perubahan di pondok pesantren Hidayatullah. Agen perubahan (Agent of Change) memimpin dalam mengubah sistem sosial. langsung tersangkut dalam tekanan- tekanan untuk mengadakan perubahan.43 Beliau banyak membuat perubahanperubahan baru dalam mewujudkan layanan prima yang memenuhi kebutuhan santri dan wali santri serta menggagas layanan prima yang terintegrasi. Sistem integrasi layanan ini diterapkan pada layanan administrasi dan layanan informasi yang berbasis data base yang bisa diakses khusus oleh pihak internal pengelola dan informasi yang dapat di akses oleh wali santri.

Perubahan organisasi adalah tindakan beralihnya sesuatu organisasi dari kondisi yang berlaku kini menuju ke kondisi masa yang akan datang menurut yang di inginkan guna meningkatkan efektivitasnya. Perubahan yang dilakukan di pondok pesantren hidayatullah, lembaga pendidikan fokus mengelola penyelenggaraan proses pendidikan dan tidak dibebani pengelolaan biaya dan pemenuhan fasiltas. Kerangka ini dibentuk oleh pimpinan pondok

${ }^{42}$ Departemen Agama, Al Qur'an dan terjemahannya, (Bandung: CV. Diponegoro, 2006), 480

${ }^{43}$ Soerjono Soekanto, Sosiologi: Suatu Pengantar. Jakarta: PT. RajaGrafindo Persada,1992), $273{ }^{54}$ Winardi, Kepemimpinan dalam ... 2000, 2 
pesantren hidayatullah untuk mempertajam peran dan fungsi lembaga pendidikan menghasilkan produk yang berkualitas dan berdaya saing. Seluruh pembiayaan di kelola terpusat, lembaga bertugas merancang anggaran pembiayaan proses pendidikan satu tahun kerja, menganalisa kebutuhan, mengajukan rancana anggaran biaya, dan menggunakan biaya operasional satu tahun yang di penuhi oleh pondok pesantren. Sarana dan prasarana pendidikan sebagai salah satu akses layanan, di situs penelitian merupakan tanggung jawab penuh pihak pondok pesantren dan lembaga binaannya mempunyai tugas menganalisa kebutuhan sarana dan mengkomunikasikan dengan pimpinan pondok pesantren untuk terealisasinya sarana prasarana yang baik.

Pemimpin yang berpengaruh, tidak melaksanakan perubahan dalam kondisi fakum, akan tetapi perubahan itu disempurnakan dengan hati-hati melalui penciptaan berbagai bagian. ${ }^{44}$ Perubahanperubahan yang dicanangkan dengan mengubah pola pendidikan pondok pesantren dengan tiga kategori yakni program salafi, program pesantren terpadu, dan program berbasis pesantren. Sistem pendidikan yang dibentuk di Pondok Pesantren Hidayatullah (Pondok Haya) ini menggunakan "Home Base Edacation System Haya" artinya sistem pendidikan yang menjadi rumah (induk) dari berbagai penyelenggaraan pendidikan di Pondok Haya, yakni program pesantren salafi (PPs) yang khusus disediakan bagi santri yang belajar di pondok saja tanpa formal, program berbasis pesantren (BP) yag disediakan khusus untuk santri yang belajar di tingkat formal dan juga belajar secara total di pondok pesantren (asrama), dan program terpadu (PT) yang disediakan bagi santri pendidikan formal dengan tambahan jam belajar 8 jam program khusus. Peran pemimpin visioner

${ }^{44}$ Paul Hersey, Kenneth h. Blanchard, Dewey E. Johnson. Management of Organizational Behavior: utility human resources, (New Yersey: Prentice Hall, 1996), 491 
adalah sebagai pelopor dan pemicu bagi berbagai perubahan yang terjadi kearah lebih baik dalam mengimplementasikan visi.45

Pemimpin adalah individu yang bertanggung jawab untuk mengubah sistem dan tingkah laku anggota organisasi. Dalam pelaksanaan pemimpin dapat mengunakan model empat langkah Lewin. Kurt Lewin dan Schein mereka berpendapat bahwa perubahan yang sukses dalam organisasi hendaknya mengikuti empat langkah, (1) keinginan untuk berubah (desire of change), sebelum perubahan terjadi setiap individu harus merasakan suatu kebutuhan, dapat berupa kekurangan-kekurangan dan ketidakpuasan selama ini serta adanya keinginan untuk meningkatkan, (2) pencairan (unfreezing), yang meliputi memberikan dorongan, membujuk melalui pendekatan-pendekatan dengan mengurangi ancaman-ancaman maupun penolakkan sehingga setiap individu siap untuk berubah, (2) merubah (changging) yang meliputi pemberian perubahan pada setiap individu melalui pembelajaran baru pada sikap mereka, dalam hal ini pekerja diberi informasi baru,model perilaku baru, dan cara baru dalam melihat sesuatu sehingga pekerja belajar dengan sikap baru. dan (3) memantapkan (refreezing) perubahan baru untuk membuat jadi permanen. ${ }^{46}$

Sebagai agen perubahan pemimpin visioner dituntut memiliki dan mengembangkan strategi dan perencanaan yang tepat dalam mencapai visi organisasi. Hal ini sesuai firman Allah dlam Al Qur'an Surat Al Hasy ayat 18:

"Hai orang-orang yang beriman, bertakwalah kepada Allah dan hendaklah Setiap diri memperhatikan apa yang telah diperbuatnya

${ }^{45}$ Nurul Hidayah, Kepemimpinan Visioner .... 2016, 82

${ }^{46}$ Stephen P. Robin, Perilaku organisasi, (Jakarta: Penerbit Salemba, 2008), 289 
untuk hari esok (akhirat); dan bertakwalah kepada Allah, Sesungguhnya Allah Maha mengetahui apa yang kamu kerjakan" 47

3. Kyai sebagai Komunikator

Seorang visonary leadership merupakan negosiator utama dalam menjalin hubungan dengan organisasi lain. ${ }^{48}$ Kyai Ma'shum dalam mengimplementasikan visi bekerja dengan menggunakan peran kepemimpinan sebagai komunikator. Peran ini tampak dari diri beliau dengan menjalin kerjasama dengan berbagai intansi dalam rangka mensukseskan layanan prima di pondok pesantren Hidayatullah. Jaringan kerjasama yang dibuat mulai lingkup regional, instansi pemerintah, berbagai dunia indsutri, dan kerjasama dengan berbagai perguruan tinggi di Jawa Timur. Kerjasama dalam bidang industri menjembatani santri yang studi di sekolah kejuruan dapat melakukan pemagangan, latihan kerja, dan nantinya ada jaminan diterima kerja sesuaiharapan santri. Demikian halnya kerjasama yang dibuat dengan berbagai perguruan tinggi negeri maupun swasta di lingkup provinsi Jawa Timur sebagai fasilitasi santri yang mempunyai keinginan melanjutkan studi ke jenjang perguruan tinggi mendapatkan jaminan diterima sesuai perguruan tinggi yang diinginkan.

Peran pemimpin organisasi yang diwujudkan dalam kegiatan organisasi (Inside the organization), peran pimpinan berinteraksi dengan staf dan tenaga sukarela untuk memberikan inspirasi, mendorong, menggerakkan dan memberdayakan mereka, ke luar organisasi (outside organization), peran pimpinan mencari bantuan, dukungan dari donatur, mitra yang berpotensi dengan para pimpinan bisnis di luar organisasi, masa operasi (present operation), pimpinan memusatkan pada kualitas dan pelayanan, pada struktur organisasi, sistem informasi dan aspek lainnya, dan masa depan (on future possiblities),

47 Departemen Agama, Al Qur'an ... 2006, 504

${ }^{48}$ Nurul Hidayah, Kepemimpinan Visioner .... 2016, 83 
pimpinan mengantisipasi trends serta mengembangkan arah masa depan organisasi. 49

Pemimpin yang bervisi akan selalu bekerja sama dengan dengan orang lain untuk mendukung suksesnya perwujudan visi organisasi. Hal ini ditegaskan dalam Al Qur'an surat Thaha ayat 44: “Maka berbicaralah kamu berdua kepadanya dengan kata-kata yang lemah lembut, Mudah-mudahan ia ingat atau takut". 50

4. Kyai sebagai Pembimbing

Pemimpin visioner yang efeketif harus menjadi pembimbing yang baik. Dengan ini berarti pemimpin harus menggunakan kerjasama kelompok untuk mencapai visi yang ditetapkan.51 Kyai Ma'shum menerapkan sistem kerjasama tim kerja dengan membentuk tim perumus visi, tim pengembangan pondok pesantren, dan tim evaluasi kinerja layanan prima pesantren yang disebut tim 6 Haya. Tim ini selalu dibawah arahan dan bimbingan Kyai Ma'shum dalam setiap langkah dan kerja yang dilakukan, dan Kyai Ma'shum berpartisipasi penuh dalam merumuskan, mengawal, dan mmewujudkan visi agar tidak berbelok dari tujuan pondok pesantren.

Selain bekerjasama dengan tim kerja yang dibentuk, Kyai Ma'shum dalam kinerjanya mewujudkan visi pondok pesantren menggunakan media rapat kerja yang diadakan setiap tiga bulanan dan kahir tahun. Rapat tersebut dimanfaatkan menjadi wahana pembinaan dan pengarahan bagi seluruh komponen pesantren mengenai visi pesantren yang harus diwujudkan sesuai tujuan visi dibentuk. Di lain sisi, Kyai setiap ketika bertemu dengan pengelola dan pendidik selalu mengarahkan dan memberikan bimbingan agar proses perwujudan visi benar-benar tercapai. seorang pemimpin dapat

\footnotetext{
${ }^{49}$ Burt Nanus and Stephen M. Dobbs. LeadersMake Different Strategies for Meeting the Non Profit Challenge, (San Francisco: Jossey Bass, 1999), 18

${ }^{50}$ Departemen Agama, Al Qur'an ... 2006, 480

51 Nurul Hidayah, Kepemimpinan Visioner .... 2016, 83
} 
berbuat banyak untuk memfasilitasi kesuksesan elaksanaan perubahan, melalui tindakan politik termasuk menciptakan koalisi, membentuk tim, memilih orang yang tepat untuk diletakkan pada posisi kunci, membuat simbol perubahan, dan memonitor serta mendeteksi persoalan yang harus diperhatikan. ${ }^{52}$

5. Kyai sebagai Uswatun Hasanah

Pemimpin visioner memberikan contoh dan teladan kepada orang lain. Keteladanan yang utama adalah ruhul jihad dan semangat memperjuangkan dan memajukan lembaga pendidikan. Keteladanan yang diterapkan oleh Kyai Ma'shum dengan selalu memberikan pengajaran setiap waktu kepada santri walaupun banyak aktifitas yang mejadi tanggung jawab beliau yakni sebagai ketua Syuriah NU kabupaten Trenggalek. Disamping melayani kepentingan umat yang beragam, beliau terus berupaya memberikan contoh melaksanakan tugas mengajar sebagaiman yang sudah ditentukan.

Keteladanan yang dicontohkan Kyai Ma'shum adalah sikap menerima siapapun tanpa diskrimanasi dengan berbagai kepentingan baik skala besar maupun kecil. Beliau selalu siap 24 jam melayani umat dengan segala bentuk permsalahan yang dihadapi. Sikap sabar dan tawadhu' selalu dicontohkan beliau kepada siapapun dengan sikap merendahkan diri. Dilain sisi beliau menunjukkan pola hidup dengan kesederhanaan, dan kepada siapapun yang datang berkunjung kepondok pesantren selalu diajak makan bersama sebagai wujud perghormatan kepada tamu dengan menu daerah pinggiran yang apa adanya.

6. Kyai Bekerja dengan Istikomah

Pemimpin visioner dituntut mempunyai komitmen tinggi dan sikap contine melaksanakan visi dalam aksi. Kerpibadian yang

52 Gay A Yulk, alih bahasa Jusuf Udaya. Kepemimpinan dalam Organisasi, (Jakarta: Prenhallindo, 1998), 300 
isitikomah ditunjukkan oleh Kyai Ma'shum dengan tak henti-hentinya mengarahkan, membina, dan mengajak seluruh komponen pesantren Hidayatullah untuk berpegang teguh pada visi dan tujuan pesantren sebagai lembaga pendidikan.

Keteladanan Kyai dengan memberikan motivasi dan spirit kepada orang lain untuk selalu berjuang memajukan pendidikan Islam. Kyai Ma'shum memberikan contoh-contoh yang baik kepada santri dan pengelola dengan istikomah sholat berjamaah, mengkaji alqur'an dan kegiatan lainnya. Pemimpin visioner melakukan upayaupaya implementasi visi kedalam budaya organisasi. Budaya merupakan aspek penting dalam sistem pendidikan yang memberikan kenyamanan bagi seseorang. Pemimpin yang visioner bercirikan keberanian mengubah, melibatkan orang lain, sikap terbuka, sportif, dan konsensus membangun kepercayaan. ${ }^{53}$

\section{Kesimpulan}

Penelitian di Pondok Pesantren Hidayatullah Pule Trenggalek tentang kemampuan Kyai mengimplementasikan visi dalam mewujudkan layanan primamenggunakan pendapat Burt Nanus menyatakan bahwa visi diwujudkan dengan kerja kepemimpinan. Kepemimpinan yang bervisi bekerja dengan empat pilar; 1) Penentu arah, 2) Agen perubahan, 3) Juru bicara, 4) Pelatih. Hasil penelitian ini menguatkan dan mengembangkan pendapat Burt Nanus tentang visi dapat diwujudkan melalui aksi kerja pimpinan dengan 1) menentukan arah, 2) agen perubahan, 3) komunikator, 4) pembimbing, 5), Uswatun Hasanah, dan 6) Istikomah (konsisten). Kemampuan Kyai mengimplementasikan visi dengan bekerja sebagai penentu arah kebijakan, agen perubahan di pondok pesantren, komunikator, pembimbing, bersikap stikomah, dan

${ }^{53}$ K. Brown \& V. Anfara, Paving the Way for change Visionary Leadership in Action at the midlle Level, National Assaociation of Secondary school principle Bulletin, Vol. 87 No. $635,2003.6$ 
menjadi Uswatun Hasanah dalam mewujudkan layan prima di pondok pesantren.

\section{Daftar Pustaka}

Aqil, Said, Siradj et.al, 1999, Pesantren Masa Depan, Wacana Pemberdayaan dan Transformasi Pesantren, Bandung: Pustaka Hidayah.

Arifin, Imron, 1994, Penelitian Kualitatif dalam Bidang Ilmu-ilmu Sosial dan Keagamaan, Malang: Kalimasada Press.

Dofier, Zamakhsyari, 1985, Tradisi Pesantren: Studi tentang Pandangan Hidup Kiai, Jakarta: LP3ES.

Fauzi, Ahmad, 2006, Pengaruh Prilaku Pemimpin dan Penggunaan Kekuasaan Terhadap Efektivitas Kepemimpinan Kepalah Sekolah Dasar Negeri Se Kota Pasuruhan, Malang, Universitas Widiya Gama Malang.

Hadari, Nawawi et all, 2004, Kepemimpinan yang Efektif, Yogyakarta: Gadjah Mada University Press.

Haedari, Amin, 2007, Transformasi Pesantren, (Jakarta: Media Nusantara,2007), 32

K. Brown \& V. Anfara, 2003, Paving the Way for change Visionary Leadership in Action at the midlle Level, National Assaociation of Secondary school principle Bulletin, Vol. 87 No. 63.

Komariyah, Aan \& Cepi Triatna, 2016, Visionary Leadership Menuju Sekolah Efektif, Jakarta: PT Bumu Aksara.

Nanus, Burt, 2001, Kepemimpinan Visioner, Jakarta; Prenhalindo.

Wahjosumidjo, 2002, Kepemimpinan Kepala Sekolah: Tinjauan Teoritis dan Permasalahannya, Cet. III., (Jakarta: PT. RajaGrafmdo Persada.

Ziemik, Manfred, 1986, Pesantren dalam Perubahan Sosial, terjemahan Bucthe B. Soedjojo, Jakarta: Media Press, Cet.I. 
Zuhri

142 | Bidayatuna, Vol. 01 No. 02 Oktober 2018 